\section{EMBRYRIDDLE}

Aeronautical University

SCHOLARLY COMMONS
Journal of Aviation/Aerospace

Education \& Research

Volume 6

Number 2 JAAER Winter 1996

Article 9

Winter 1996

\title{
The Edwards Personal Preference Schedule as a Predictor of Success in a Collegiate Professional Pilot Training Program
}

Ronald J. Ferrara

Follow this and additional works at: https://commons.erau.edu/jaaer

\section{Scholarly Commons Citation}

Ferrara, R. J. (1996). The Edwards Personal Preference Schedule as a Predictor of Success in a Collegiate Professional Pilot Training Program. Journal of Aviation/Aerospace Education \& Research, 6(2).

https://doi.org/10.15394/jaaer.1996.1176

This Article is brought to you for free and open access by the Journals at Scholarly Commons. It has been accepted for inclusion in Journal of Aviation/Aerospace Education \& Research by an authorized administrator of Scholarly Commons. For more information, please contact commons@erau.edu. 


\title{
THE EDWARDS PERSONAL PREFERENCE SCHEDULE AS A PREDICTOR OF SUCCESS IN A COLLEGLATE PROFESSIONAL PILOT TRAINING PROGRAM
}

\author{
Ronald J. Ferrara
}

This study examined the preliminary results of a project designed to identify a method to predict successful student completion of a collegiate professional pilot curriculum. The study undertook to evaluate the Edwards Personal Preference Schedule (EPPS) as a predictive instrument. The EPPS was administered to 185 collegiate professional pilot candidates. The results were analyzed by means of a stepwise regression analysis. The findings indicated that only two variables were statistically significant in explaining the variance. These variables were Change and Autonomy. In combination, these variables explained approximately $4.8 \%$ of the total variance. Due to the low percentage of the total variance explained, the value of the EPPS as a predictor of success in collegiate professional pilot curricula must be seriously questioned.

\section{INTRODUCTION}

Aviation safety is a function of a number of human factors-related variables. Among these variables are the quality of flight training received and such individual characteristics as attitude, judgment, leadership, decision making, and interpersonal skills. As human factors are, in large part a result of training and experience, any attempt to improve aviation safety will of necessity involve the selection and training process. An improved, more efficient method of selecting and training flight crew personnel is a central concern in today's aviation industry. This is especially true in view of the changing role of the pilot in terms of cockpit resource management and crew coordination (Foushee, 1982; Foushee \& Helmreich, 1988; Moll, 1989; Sams, 1987). Public and industry attention increasingly have been focused on crew coordination, training, and performance. This is due, at least in part, to the unusually high number of accidents and fatalities in the aviation industry in 1994, particularly by the commuter segment.

The efficacy of traditional methods of selecting and training professional pilots is being challenged. Often the allegation is made that traditional selection and training methods can no longer adequately meet the needs of today's rapidly changing aviation industry. Coincidentally, due to the high cost of initial and recurrent flight training to both the individual and the potential employer, the ability to predict success in training and long-term retention has become an important consideration in the industry.

\section{PURPOSE OF THE STUDY}

The purpose of this study was to examine the value of the EPPS as a predictive instrument in a collegiate professional pilot training program. The EPPS has been used to establish norms for both male and female college students and has been widely used in examining pilot personality profiles. Thus, it served as a starting point in an attempt to establish a correlation between scores on certain identified personality factors and successful completion of the professional pilot degree program. The EPPS has been shown to be a relatively robust instrument for differentiating among groups of different occupations and between successful and unsuccessful workers in an occupation (Ashman \& Tefler, 1983). In view of the ever-increasing role of collegiate aviation education programs in the training of pilots and flight crew members for the air transportation industry, it was appropriate that this attempt at identifying those potential pilots and flight crew members with the highest potential for success be examined in the collegiate environment.

\section{REVIEW OF RELATED LITERATURE}

The judgment and decision-making abilities of a pilot are critical factors in aviation safety. Traditionally, the aviation community has felt that pilot judgment is innate or acquired over time with experience. It has been 
historically accepted, at least to a significant degree, that a certain personality type made the best pilots (Ferrara, 1994). Not until recently has judgment been considered a subject of formal training (Bowman, 1994; Buck \& Diehl, 1984). Cook has stated that "Since pilot errors continue to be a major contributor to commercial aircraft accidents, work to improve the human system holds the greatest promise for improving airline safety" (Cook, 1991, p. 33).

Calls for standardization and a more efficient method of selecting pilots and flight crews have become commonplace as the industry searches for the most qualified personnel. As Walters wrote:

Certainly there is evidence among the more farsighted airlines that more attention needs to be paid to the pilot selection process, whether at the stage when young applicants are considered for $a b$ initio training, or simply when recruiting qualified pilots to meet current needs. (1994, p. 18)

These pleas for improved selection criteria have been reinforced by the steady percentage of accidents and incidents directly attributable to pilot and flight crew error. According to Federal Aviation Administration data, human error is identified as a causal factor in $66 \%$ of fatal air carrier accidents, in $79 \%$ of fatal commuter accidents, and in $88 \%$ of fatal general aviation accidents. Other estimates of pilot error as a contributing cause of accidents run as high as $90 \%$ (Bowman, 1994). Although traditional selection procedures in the airline industry have relied on measuring psychomotor and technical skills (Pettit \& Dunlap, 1994), it is a fact that less than $30 \%$ of crew-caused accidents result from technical crew performance failure. However, $70 \%$ of crew-caused accidents are the result of human factors crew performance failures (The CRM Advocate, 1993). Aviation, particularly in the United States, has tended to rely on developing technological solutions to any problems that arise. We must at least consider that human solutions to operating problems may provide a greater benefit at lower cost, rather than relying totally on technological solutions. The ever-escalating expense of increasingly complex and exotic technical solutions may indeed be cost-prohibitive as well as ineffective.
A fairly well-developed body of evidence suggests that various need factors can be identified and used as normative data to predict success in stressful occupations such as aviation (Helmreich, Foushee, Benson, \& Russini, 1986; Meir \& Keinan, 1980; Reinhardt, 1970; Ryman \& Biersner, 1975). This has resulted in increased interest in the air transportation industry for early identification of those aspiring cockpit crew members who are most likely to succeed. Since the selection and post-training retention of highly trained professional pilots and crew members is a primary concern of the air transportation industry, identifying those with the highest probability of success is important to the industry.

Historically, the airline industry has used aptitude tests in an attempt to predict success in primary flight training and later pilot retention. Because aptitude tests have proven to have validity correlations of between .15 and .25 to a pass-fail criterion for pilot training (Dolgen \& Gibb, 1989), attention is shifting to measuring personality variables and decision-making styles to improve the selection methods. Foushee and Helmreich (1988) argue that the traditional pilot selection and training methods are, at least in part, responsible for many of the problems associated with pilots. It may also explain, in part, the fact that it is the older, more experienced pilots that seem to have the most difficulty adjusting to the changing demands of airline operations. After analyzing the cost and effectiveness of post-hire training, Helmreich (1984) argued that

There is evidence that personality is linked to pilot performance. ... If personality is the predominant determinant of cockpit management behavior, then airline managers should concentrate on pilot selection rather than training, and allow cockpit management to gradually improve with retirement of the pilots with inappropriate personality traits.

Recently commercial flight-simulator manufacturers have shown interest in developing methods to evaluate candidates with a focus on "the characteristics expected of an airline pilot" (Walters, 1994, p. 18). This procedure involves a series of integrated testing with increasing stress levels, thus measuring more than just the piloting ability of the candidate. 


\section{RESEARCH METHODOLOGY}

The instrument used in this research was the EPPS. This study was descriptive in nature, in that scores on specific factors of the EPPS were used from a population sample that was not randomly determined. The EPPS is a 224question, forced-choice inventory based on Murray's Theory of Human Needs (Ashman \& Tefler, 1983). The EPPS was developed in response to the discovery that there were large differences in effective job performance between people of approximately equal ability levels. The EPPS was designed to assess various characteristics with the goal of improving vocational counseling and selection procedures while controlling for the factor of social desirability. This instrument has been widely used in predicting success and failure and identifying dropouts in technical programs (Belcastro, 1979; Glenn, Rollins, \& Smith, 1990; Knopke, 1979).

The EPPS identifies 15 characteristics defined as:

1. Achievement (Ach): successfully doing one's best, attainment.

2. Deference (Def): following instructions, doing what is expected, letting others make decisions.

3. Order (Ord): planning activities, having things organized, neatness.

4. Exhibition (Exh): being the center of attention, being noticed by others.

5. Autonomy (Aut): Independence, unconventional.

6. Affiliation (Aff): being loyal to friends, to develop strong attachments.

7. Intraception (Int): empathy, to analyze one's feelings and emotions.

8. Succorance (Suc): to seek encouragement, to seek aid and understanding from others.

9. Dominance (Dom): to be a leader in groups, to supervise or influence others.

10. Abasement (Aba): to feel guilty when one does something wrong, timidity.

11. Nurturance (Nur): to be sympathetic to others, to assist others.

12. Change (Chg): to do new and different things, to travel.

13. Endurance (End): tenacity, to keep at a job until it is finished.

14. Heterosexuality (Het): to be regarded as attractive to the opposite sex.

15. Aggression (Agg): to attack contrary points of view, to be critical of others. (Ashman \& Tefler, 1983; Edwards, 1959).

\section{Procedure}

The EPPS was administered to 185 professional pilot candidates at Middle Tennessee State University. Of the subjects tested, 163 test results were considered usable. The subject population was divided into three distinct groups to indicate the status of the candidate:

1: Candidates presently enrolled. $n=110$

2: Non-completers. $n=30$

3: Completers. $n=23$

Successful completion was defined as graduation with the bachelor of science degree with a commercial flight certificate and an instrument rating. Non-completers were defined as those who did not complete the degree requirements or who changed their major before graduation. The scores of successful completers were then compared by means of a statistical analysis to those who left the program before completion.

\section{Statistical Analysis}

A stepwise multiple-regression analysis was performed to test the hypothesis that there was no significant relationship between scores on the EPPS and successful completion of the professional pilot curriculum. The computer facilities of Middle Tennessee State University were used for statistical processing. The Statistical Package for The Social Sciences (SPSS) was considered the appropriate software using a .05 level of significance.

\section{RESULTS}

Research Question: Do selected profile factors as measured by the EPPS relate to successful completion of degree and pilot certification requirements?

This question was examined by means of a stepwise regression analysis. This statistical method was used to examine any interrelationships between factors on the EPPS and the status of the subject. The dependent variable was status (completer/non-completer) and the independent variables were the scores on the EPPS. Equation:

$H(r)$ : There will be a positive relationship between the scores on selected items of the EPPS and successful completion of the professional pilot curriculum $(r>0)$. 
Table 1

Regression Analysis Status as a Function of EPPSFactors.

$(\mathrm{N}=163)$

Variable entered in step 1: Change

Multiple R: . 17930

R Square: .03215

Adjusted R Square: .02614

Standard Error: .72138

ANALYSIS OF VARIANCE

$\begin{array}{lccccc} & \text { df } & \text { Sum of Squares } & \text { Mean Squares } & \text { F } & \text { Sig F } \\ \text { Regression } & 1 & 2.78293 & 2.78293 & 5.34786 & .0220 \\ \text { Residual } & 161 & 83.78149 & .52038 & & \end{array}$

Variable entered in step 2: Autonomy

Multiple R: .24480

R Square: .05993

Adjusted R Square: .04818

Standard Error: .71317

ANALYSIS OF VARIANCE

$\begin{array}{lccccc} & \text { df } & \text { Sum of Squares } & \text { Mean Squares } & \text { F } & \text { Sig F } \\ \text { Regression } & 2 & 5.18761 & 2.59381 & 5.09984 & .0071 \\ \text { Residual } & 160 & 81.37681 & .50861 & & \end{array}$

Variables Used In Equation

$\begin{array}{lc}\text { Variable } & \text { Significant F } \\ \text { Change } & .0265 \\ \text { Autonomy } & .0311\end{array}$

\section{Variables Not Used in Equation}

$\begin{array}{lc}\text { Variable } & \text { Significant F } \\ \text { Achievement } & .1690 \\ \text { Deference } & .2002 \\ \text { Order } & .5225 \\ \text { Exhibition } & .8417 \\ \text { Affinity } & .3103 \\ \text { Intraception } & .2416 \\ \text { Succorance } & .3689 \\ \text { Dominance } & .5271 \\ \text { Abasement } & .6535 \\ \text { Nuturance } & .3575 \\ \text { Endurance } & .4748 \\ \text { Heterosexuality } & .2980 \\ \text { Aggression } & .7003\end{array}$


$\mathrm{H}_{\mathrm{o}}: \boldsymbol{\mu}_{1}-\boldsymbol{\mu}_{2}=0$.

$\mu_{1}=$ mean scores for program completers.

$\mu_{2}=$ mean scores for non-completers.

In this analysis the factors of Change and Autonomy were identified as the two most significant variables when considering status as a function of EPPS factors (see Table 1). The factor of Order also was found to be marginally significant when considered alone, but due to the low correlation it was not included in the regression. This combination of factors explained approximately $4.8 \%$ of the total variance using adjusted $R$ Square as the measure, with Change accounting for approximately $2.6 \%$ and Autonomy accounting for approximately $2.2 \%$ of the total variance.

\section{CONCLUSIONS AND IMPLICATIONS}

Although this study represents merely a preliminary analysis of the data collected, the results clearly did not confirm or support the value of the EPPS as a predictive instrument for the successful completion of degree and certification requirements in the professional pilot curriculum examined. Of the 15 variables considered in the analysis, only Change and Autonomy displayed any degree of statistical significance. The combination of these two factors explained about $4.8 \%$ of the total variance. This evidence leads to the conclusion that the scores on the EPPS, at best, only marginally relate to successful completion of the professional pilot curriculum. Therefore, the results suggest that the EPPS has limited, if any, value as a tool for selection or admission to the particular curriculum when used independently of other measures.

This study has serious implications in the attempt to develop an instrument to reliably identify those candidates most likely to successfully complete a collegiate professional pilot degree program. The value of the EPPS must be seriously questioned as a predictor of success in such a program. If the EPPS is used as an instrument for selection, it must be used only in conjunction with other instruments in attempting to predict performance. Additional research is needed in this area to develop an effective instrument to be used as a tool in the selection of professional pilot candidates with the greatest potential for successful program completion. $\square$

Ronald J. Ferrara earned an Ed.D. in Vocational Education from the University of Kentucky. He is an associate professor serving as chairman of the Department of Aerospace at Middle Tennessee State University.

\section{REFERENCES}

Ashman, A., \& Tefler, R. (1983). Personality profiles of pilots. Aviation, Space and Environmental Medicine, 54(10), 940-943.

Belcastro, F.P. (1979). Personality and interest characteristics of completers and noncompleters of a secondary teaching program. College Student Joumal, 13(1), 73-76.

Bowman, T. S. (1994). Aeronautical decision-making and University Aviation Association certified flight instructors. The Journal of Aviation/Aerospace Education \& Research, 4(3), 10-16.

Buck, G., \& Diehl, A. (1984). An investigation of the effectiveness of pilot judgment training. Human Factors, 26(5), 557-564.

Cook, G. N. (1991, Spring). Cockpit resource management training: Are current instructional methods likely to be successful? The Journal of Aviation/Aerospace Education \& Research, 1(3), 26-35.

The CRM Advocate. (1993, October). Issue 93-1.

Dolgen, D., \& Gibb, G. (1989). Personality assessment in aviation selection. In R. Jensen (Ed.), Aviation psychology (pp. 288-320). Montpelier, VT: Graves Publishers.

Edwards, A. (1959). Edwards personal preference manual. New York: The Psychological Corporation.

Ferrara, R. J. (1994). Testing for the existence of the pilot personality profile in collegiate professional pilot candidates. 
The Journal of Aviation/Aerospace Education \& Research, 4(2), 17-21.

Foushee, H. C. (1982). The role of communications, socio-psychological, and personality factors in the maintenance of crew coordination. Aviation, Space and Environmental Medicine, 53(10), 1062-1066.

Foushee, H. C., \& Helmreich, R. (1988). Group interaction and flight crew performance. In E. C. Wiener \& D. C. Nagel (Eds.), Human factors in aviation (pp. 189-227). San Diego: Academic Press.

Glenn, L., Rollins, N., \& Smith, B. (1990). Journal of College Student Development, 31(3), 280-281.

Helmreich, R. L. (1984). Cockpit management attitudes. Human Factors, 26(5), 583-589.

Helmreich, R. L., Foushee, C., Benson, R., \& Russini, W. (1986). Cockpit resource management: Exploring the attitude performance linkage. Aviation, Space and Environmental Medicine, 57(12), 1198-1200.

Knopke, H. J. (1979). Predicting student attrition in a baccalaureate curriculum. Nursing Research, 28(4), $224-227$.

Meir, E. I., \& Keinan, G. (1980). Prediction of success in a stressful career by personality attributes. Aviation, Space and Environmental Medicine, 51(4), 388-390.

Moll, N. (1989). Teaching teamwork. Flying, 116(3), 84-85.

Pettit, M., \& Dunlap, J. H. (1994, September). A comparison of personality characteristics between university aviation students and airline pilots. In Ballard M. Barker (Ed.), Collegiate aviation review (pp. 14-21). Auburn: University Aviation Association and Florida Institute of Technology.

Reinhardt, R. (1970). The outstanding jet pilot. American Journal of Psychiatry, 127(6), 732-736.

Ryman, D. H., \& Biersner, R. D. (1975). Attitudes predictive of diving success. Personal Psychology, 28(2), 181-188.

Sams, T. L. (1987). Cockpit resource management and training strategies. (Doctoral dissertation, East Texas State University, 1987). Dissertation Abstracts International, 49(04), 798-A.

Walters, B. (1994). New developments in pilot selection. Civil Aviation Training, 5(6), 18-20. 